\title{
Review
}

\section{Antibiotics in Necrotizing Soft Tissue Infections}

\author{
Tomas Urbina ${ }^{1,2}$ (D), Keyvan Razazi ${ }^{3,4}$, Clément Ourghanlian ${ }^{5,6}$, Paul-Louis Woerther ${ }^{7,8}$, Olivier Chosidow ${ }^{8,9}$ (D), \\ Raphaël Lepeule ${ }^{6}$ and Nicolas de Prost ${ }^{3,4, * \text { (D) }}$
}

1 Médecine Intensive Réanimation, Hôpital Saint-Antoine, Assistance Publique-Hôpitaux de Paris (AP-HP), 75571 Paris, France; tomas.urbina@aphp.fr

2 Sorbonne Université, Université Pierre-et-Marie Curie, 75001 Paris, France

3 Médecine Intensive Réanimation, Hôpitaux Universitaires Henri Mondor-Albert Chenevier, Assistance Publique-Hôpitaux de Paris (AP-HP), 94010 Créteil, France; keyvan.razazi@aphp.fr

4 Groupe de Recherche Clinique CARMAS, Faculté de Médecine, Université Paris Est Créteil, 94010 Créteil, France

5 Service de Pharmacie, Hôpitaux Universitaires Henri Mondor-Albert Chenevier, Assistance Publique-Hôpitaux de Paris (AP-HP), 94010 Créteil, France; clement.ourghanlian@aphp.fr

6 Unité Transversale de Traitement des Infections, Département de Prévention, Diagnostic et Traitement des Infections, Hôpitaux Universitaires Henri Mondor-Albert Chenevier, Assistance Publique-Hôpitaux de Paris (AP-HP), 94010 Créteil, France; raphael.lepeule@aphp.fr

7 Département de Prévention, Diagnostic et Traitement des Infections, Hôpitaux Universitaires Henri Mondor-Albert Chenevier, Assistance Publique-Hôpitaux de Paris (AP-HP), 94010 Créteil, France; paul-louis.woerther@aphp.fr

8 Research Group Dynamic, Faculté de Santé de Créteil, Université Paris-Est Créteil Val de Marne (UPEC), 94010 Créteil, France; olivier.chosidow@aphp.fr

9 Service de Dermatologie, Hôpitaux Universitaires Henri Mondor-Albert Chenevier, Assistance Publique-Hôpitaux de Paris (AP-HP), 94010 Créteil, France

check for updates

Citation: Urbina, T.; Razazi, K.; Ourghanlian, C.; Woerther, P.-L.; Chosidow, O.; Lepeule, R.; de Prost, N. Antibiotics in Necrotizing Soft Tissue Infections. Antibiotics 2021, 10, 1104. https://doi.org/10.3390/ antibiotics10091104

Academic Editor: David P. Nicolau

Received: 27 August 2021

Accepted: 10 September 2021

Published: 13 September 2021

Publisher's Note: MDPI stays neutral with regard to jurisdictional claims in published maps and institutional affiliations.

Copyright: (c) 2021 by the authors. Licensee MDPI, Basel, Switzerland. This article is an open access article distributed under the terms and conditions of the Creative Commons Attribution (CC BY) license (https:/ / creativecommons.org/licenses/by/ $4.0 /)$.
* Correspondence: nicolas.de-prost@aphp.fr; Tel.: +33-1-49-81-23-94

\begin{abstract}
Necrotizing soft tissue infections (NSTIs) are rare life-threatening bacterial infections characterized by an extensive necrosis of skin and subcutaneous tissues. Initial urgent management of NSTIs relies on broad-spectrum antibiotic therapy, rapid surgical debridement of all infected tissues and, when present, treatment of associated organ failures in the intensive care unit. Antibiotic therapy for NSTI patients faces several challenges and should (1) carry broad-spectrum activity against gram-positive and gram-negative pathogens because of frequent polymicrobial infections, considering extended coverage for multidrug resistance in selected cases. In practice, a broadspectrum beta-lactam antibiotic (e.g., piperacillin-tazobactam) is the mainstay of empirical therapy; (2) decrease toxin production, typically using a clindamycin combination, mainly in proven or suspected group A streptococcus infections; and (3) achieve the best possible tissue diffusion with regards to impaired regional perfusion, tissue necrosis, and pharmacokinetic and pharmacodynamic alterations. The best duration of antibiotic treatment has not been well established and is generally comprised between 7 and 15 days. This article reviews the currently available knowledge regarding antibiotic use in NSTIs.
\end{abstract}

Keywords: necrotizing soft tissue infections; antibiotic; pharmacokinetics; pharmacodynamics; tissue diffusion; anti-toxinic; piperacillin-tazobactam; clindamycin; beta-lactam

\section{Introduction}

Necrotizing soft tissue infections (NSTIs) are rare life-threatening bacterial infections characterized by an extensive necrosis of skin and subcutaneous tissues. NSTIs can affect any part of the body but the extremities_-particularly the lower limbs-are most frequently involved [1-4]. Most patients developing NSTIs have previous comorbidities, including diabetes mellitus, obesity, cardiovascular disease, intravenous drug use, and immunosuppression [1-3]. Infection can spread after traumatic injuries, minor breaches of the 
skin or mucosa, and even non-penetrating soft tissue injuries [1]. Mortality ranges from 10 to $30 \%$ according to initial patient severity, and morbidity among survivors includes potential amputations and profound impact on long-term health-related quality of life [5-7]. Initial urgent management of NSTIs relies on broad-spectrum antibiotic therapy, rapid surgical debridement of all infected tissues and, when present, treatment of associated organ failures in the intensive care unit. The time to surgery is one of the main modifiable prognostic factors with, in a recent meta-analysis, a significantly lower mortality rate when surgery was performed within six hours of hospital admission [8]. High-volume centers, caring for at least three patients per year, may also contribute to improving prognosis [9].

As a consequence of their rarity, data on optimal antibiotic treatment in NSTI are scarce [10] and current guidelines [11-14] are mainly derived from observational studies and experimental data. Antibiotic therapy for NSTI patients faces several challenges and should ideally achieve the following goals: (1) carry broad-spectrum activity against gram-positive and gram-negative pathogens because of frequent polymicrobial infections, considering extended coverage for multidrug resistance in selected cases; (2) decrease toxin production, mainly in proven or suspected group A streptococcus (GAS) infections; and (3) achieve the best possible tissular diffusion in the face of impaired regional perfusion, tissue necrosis, and pharmacokinetic and pharmacodynamic alterations among these frequently critically-ill patients.

The aim of this article is to review the currently available knowledge regarding antibiotic use in NSTIs and provide clinicians with a practical tool to use at bedside.

\section{Microbiology of NSTIs}

Causative organisms vary widely according to infection site, underlying conditions, but also from one region of the world to the other [4,15-18]. In most cases, the infection is polymicrobial (so-called type I infections), involving gram-positive cocci, Enterobacteriaceae, nonfermenting bacilli and anaerobic bacteria. Anaerobic, aerobic, and facultative anaerobic bacteria act synergistically and fuel a cycle of bacterial colonization and inflammatory tissue necrosis [19]. However, approximately one third of NSTIs are monomicrobial (type II infections), involving mainly GAS and Staphylococcus aureus $[4,7,19,20]$. Although predominant in monomicrobial and upper-extremity infections, GAS can be documented in up to $40 \%$ of NSTIs overall [21]. A recent study has highlighted that streptococcal NSTIs were associated with different host responses than polymicrobial NSTIs, with a higher expression of interferon-inducible mediators and lower expression of extracellular matrix components [19]. In some series, S. aureus was reported to be more prevalent than GAS in monomicrobial NSTIs [18]. Community-associated methicillin-resistant S. aureus carrying the Panton-Valentine leucocidin was reported in the United States [22,23]. Classic clostridial gangrenes have become rare, while the incidence of gram-negative infections and multi-drug resistant organisms is increasing [21,24]. The most commonly isolated microorganisms are summarized in Table 1. 
Table 1. Most frequently cultured microorganisms in NSTI. Classification adapted from Bruun et al. [25].

\begin{tabular}{|c|c|c|c|c|}
\hline Type of Pathogens & Primary & Secondary & Polymicrobial & Commensals \\
\hline Pathogenicity & $\begin{array}{l}\text { May cause NSTI in patients without } \\
\text { known risk factors }\end{array}$ & May cause infection in patients with risk factors & $\begin{array}{l}\text { Rarely pathogen in the absence of a } \\
\text { primary or secondary pathogen }\end{array}$ & $\begin{array}{l}\text { Do not cause NSTI although } \\
\text { sometimes identified with other } \\
\text { pathogens }\end{array}$ \\
\hline Species & $\begin{array}{l}\text { Group A Streptococcus } \\
\text { Staphylococcus aureus } \\
\text { Vibrio vulnificus } \\
\text { Clostridium perfringens }\end{array}$ & $\begin{array}{c}\text { Other Streptococcus (group B, C, G, anginosus) } \\
\text { Pneumococcus } \\
\text { Haemophilus influenzae } \\
\text { Neisseria meningitidis } \\
\text { Enterobacteriaceae } \\
\text { Nonfermenting gram-negative bacilli } \\
\text { Other anaerobes (Bacteroides, Prevotella, } \\
\text { Fusobacterium) }\end{array}$ & Enterococcus & $\begin{array}{c}\text { Bacillus } \\
\text { Corynebacterium } \\
\text { Micrococcus } \\
\text { Coagulase negative Staphylococci }\end{array}$ \\
\hline
\end{tabular}




\section{Microbial Documentation of NSTIs: A Challenge for Microbiologists}

Because of their uncertain contribution to the microbiological diagnosis, superficial samples should be avoided [26]. Contrariwise, deep samples collected at the interface between healthy and necrotized tissues by the surgeon during initial debridement and blood cultures are paramount, allowing for the identification of causative pathogens in approximatively $90 \%$ of cases $[17,19,27,28]$. As for any other deep suppuration, surgical samples are affixed on slides and Gram stained for extemporaneous microscopic direct examination. The detection of yeasts or the visualization of staphylococci, possibly leading to the use of rapid molecular tools aiming to detect methicillin resistant Staphylococcus aureus (MRSA), can have an immediate impact on antimicrobial treatment. As recommended by the European Society of Clinical Microbiology and Infectious Diseases (ESCMID) [29], samples are seeded on solid and liquid media and incubated for up to 5 days, in order to grow all the present bacteria, including anaerobes and difficult-to-grow bacteria. Because of the deep nature of the studied samples and the severity of NSTI, all growing bacteria of medical interest should be identified, and their antibiotic susceptibility tested. Nevertheless, as presented in Table 1, pathogenecity of different micro-organisms is still a matter of debate $[25,30]$.

The emergence of next-generation sequencing (NGS) methods is transforming medical diagnosis, including in infectious diseases. These methods include targeted metagenomics in which a PCR step (aiming to restrict the panel of microorganisms searched similarly to the $16 \mathrm{~S}$ metagenomics for bacteria) precedes the sequencing, and shotgun metagenomics, a method consisting in sequencing the whole extracted nucleic acids (DNA and/or RNA). In the latter case, after subtraction of human sequences, analysis of the remaining reads leads to the identification of all the microorganisms present, including bacteria, viruses, yeasts, or parasites. Like in many other situations [31-33], shotgun metagenomics has demonstrated its better ability to detect a broad range of pathogens, particularly strict anaerobes compared to other methods [34]. Interest for this method is enhanced by the recent description of a complex pathobiome in NSTIs, urging to broadly identify all present microorganism both in necrotic and macroscopically healthy tissue [20]. Furthermore, ongoing developments of shotgun metagenomics may in the future add genomic information by detecting virulence or resistance determinants that could improve clinical management [35].

\section{Antibiotic Treatment}

As discussed above, prospective or controlled data regarding antibiotic treatment specifically for NSTIs is scarce, with recommended antibiotic regimens mainly based on expert consensus. Some knowledge can however be derived from infections sharing similar characteristics, including non-necrotic skin and soft tissue infections, acute pancreatitis necrosis infection, or conditions with impaired regional perfusion such as diabetic foot or limb ischemia infection.

We will present available data on the choice of molecules and modalities of treatment, before proposing a pragmatic antibiotic treatment scheme for suspected NSTI.

\subsection{Available Data Regarding Choice of Molecules Specifically in NSTIs}

As reported in a meta-analysis of randomized trials on antibiotics in complicated skin and soft-tissue infections [36], there is no evidence to support the use of one antibiotic over others. One open label randomized trial evaluated moxifloxacin versus amoxicillinclavulanate in 804 patients with complicated skin infections, which included 54 NSTIs [37]. There was no difference in clinical success rate, both in the whole population $(80.6 \%$ vs. $84.5 \%$ ) or in the subgroup of NSTI patients ( $50.0 \%$ vs. $53.8 \%$ ). One non-interventional uncontrolled prospective study reported tigecycline use in 163 ICU-admitted patients with complicated skin infections, including 50 NSTI patients [38]. Tigecycline was used as a second-line treatment in $80 \%$ of patients, and as a single agent in $64 \%$ of cases. The reported cure rate was $90.2 \%$. Likewise, although all were approved for complicated skin 
and soft tissue infections by non-inferiority trials, there is no evidence for a benefit to recent molecules such as daptomycin, ceftaroline, or ceftobiprole.

The only molecule evaluated in higher numbers of NSTI patients is clindamycin, although the available literature, which is discussed below, mostly included invasive GAS infections overall.

\subsection{Specificities for GAS Infections: Anti-Toxinic Molecules}

Pathogenicity of GAS NSTI seems to largely rely on the bacterial toxins that induce a strong immune response, including polyclonal T-cell activation and cytokine release. Although GAS infections remain highly susceptible to beta-lactams, particularly penicillin, association with clindamycin is strongly recommended in the case of NSTI [11]. Clindamycin is a lincosamine derivative, inhibiting protein synthesis by binding to the $50 \mathrm{~S}$ subunit of bacterial ribosomes, and retaining bacteriostatic activity on stationary-growth phase bacteria in a mouse model [39]. In line with its mechanism of action, in vitro studies have demonstrated the capacity of clindamycin to significantly inhibit the production of pyrogenic exotoxins SPE-A and SPE-B, also known as superantigenic exotoxins [40,41], as well as other major virulence factors implicated in severe GAS infections [42]. Experimental data from animal models underline the importance of using high doses of clindamycin, as increased protein expression can be observed when subinhibitory clindamycin concentrations are administered [43].

Interestingly, the anti-toxinic benefits of clindamycin were reported regardless of strain susceptibility [43]. Moreover, clindamycin does not appear to be susceptible to inoculum size through—the so-called Eagle effect-as opposed to penicillin $[39,44]$. In a recent epidemiological study in Spain assessing the resistance profile of invasive Streptococcus pyogenes isolates $(n=1893)$, clindamycin resistance was found in only $4.3 \%$ of cases [45], but up to $14.6 \%$ in the USA [46], and clindamycin should thus not be used as an empirical monotherapy.

Observational studies have suggested a benefit of clindamycin as an adjunctive treatment in patients with invasive GAS (iGAS) infections, including NSTIs, supporting current recommendations by professional societies [11]. Carapetis et al. reported 84 cases of iGAS infection, of whom clindamycin-treated patients had more severe disease than clindamycinuntreated patients but lower mortality at day 30 (15\% vs. 39\%), with a significantly protective odds ratio for death in univariate but not in multivariate analysis adjusting for the presence of streptococcal toxic shock syndrome and age [47]. Recently, Babiker et al. performed a propensity-matched analysis on a retrospective multicenter cohort including 1079 patients with iGAS infections (including 275 skin and soft tissue infections (SSTIs) but only 12 NSTIs), 343 of whom had received clindamycin adjunct. In the propensity-matched cohort, mortality was significantly lower in patients who received adjunctive clindamycin compared to those who did not (6.5\% vs. $11.0 \%)$ [48]. Interestingly, such an effect was not confirmed in patients with invasive non-group A/B $\beta$-haemolytic streptococcal infections.

Although less documented, linezolid, a member of the oxazolidinone class which also binds the $50 \mathrm{~S}$ ribosomal subunit, might have comparable in vitro consequences on the toxin release by GAS [49].

\subsection{Perspectives on Other NSTI Specificities}

Recent studies, extensively by the INFECT study group [30], have highlighted other specificities of NSTIs that could impact antibiotic treatment, including the existence of a complex pathobiome in polymicrobial infection [20], of biofilm formation in GAS infections [50], and the intracellular survival of pathogens such as S. aureus and GAS [51]. The clinical implications of such findings, i.e., the benefit of using antibiotics particularly active in the setting of biofilm like rifampicin, or with high intracellular concentrations, such as macrolides or tetracyclines, are yet to be determined. 


\subsection{Duration of Treatment and De-Escalation}

No study has evaluated the impact of treatment duration on NSTI outcome, resulting in heterogenous practices [52]. Guidelines suggest maintaining treatment for $48-72 \mathrm{~h}$ after the last surgery [11], as this delay seems adequate to asses clinical improvement including the absence of fever [53]. Although there is no data specifically on NSTI, antibiotic deescalation based on microbiological documentation from blood cultures and preoperative samples seems appropriate.

\section{Pharmacokinetics (PK) and Pharmacodynamics (PD) Targets and Optimization}

The mainstem of urgent empirical antibiotic treatment for NSTI is a broad spectrum B-lactam. These antibiotics display time-dependent activity, where bacterial killing and treatment efficacy correlate with the duration of time that free (unbound) plasma drug concentrations remain above the minimum inhibitory concentration (MIC) of the offending pathogen (fT > MIC) [54]. One major consequence of septic shock, which affects half of NSTI patients [4], is the intense vasodilation and extravasation of fluid into the interstitial space from endothelial damage and capillary leakage. This phenomenon is commonly described as 'third spacing'. In response to the resulting hypotension, clinicians administer large volumes of resuscitation fluids that may also distribute into interstitial space, thereby significantly increasing interstitial volume. For hydrophilic antibiotics, these processes may lead to a large increase in the distribution volume $(\mathrm{Vd})$, an extensively documented phenomenon in critically ill patients [55].

In addition, hypoalbuminaemia is a common but frequently neglected condition in septic patients. With decreasing albumin concentrations, an increase in the unbound fraction of drugs can occur. The unbound fraction of antibiotics is not only available for elimination, but also for distribution. The Vd for moderate to highly protein-bound antibiotics can thus increase by up to $100 \%$ in critically ill patients with hypoalbuminaemia $[56,57]$. Overall, the $\mathrm{Vd}$ of antimicrobials may increase up to 3-fold in critically ill patients, requiring an initial high-loading dose [58,59].

Lastly, severe infections can cause vascular dysfunction, including microvascular failure, which can impair drug delivery into body tissues, particularly in patients with sepsis being treated with vasopressors. In this context, plasma concentrations may profoundly underestimate tissue concentrations [60].

There is evidence defining the impact of early and appropriate antibiotic administration on decreased mortality [61,62]. In sepsis studies, interventions aimed at optimizing antibiotic therapy demonstrate the greatest improvements in clinical outcomes [63,64]. Convincing in vitro, animal and clinical data also suggest that microbiological success may be optimal when serum $\beta$-lactam concentrations are maintained above $4 \times$ MIC during the entire time frame [65-69]. The results of the DALI study indeed support the conclusions that better outcomes for critically ill patients can be expected with higher drug exposures [63]. Prolonged infusion schemes increase the fraction of the dose interval in which unbound antibiotic concentrations exceed the MIC of the pathogen (fT > MIC), as compared with standard intermittent infusion [64,70-74]. A meta-analysis showed that hospital mortality was significantly lower (RR, $0.74 ; 95 \% \mathrm{CI}, 0.56-1.00 ; p=0.045)$ and clinical cure significantly higher $(\mathrm{RR}, 1.20 ; 95 \% \mathrm{CI}, 1.03-1.40 ; p=0.021)$ in the continuous infusion group than in the intermittent infusion group in severe patients [75]. In a meta-analysis of randomized trials, the risk of death in patients with sepsis treated with prolonged infusion of anti-pseudomonal $\beta$-lactams was $30 \%$ lower compared with patients treated with short term infusion [76], a finding confirmed in another meta-analysis focusing on piperacillintazobactam [77]. However, the stability over time of the drug solution may challenge the continuous infusion of some antibiotics (e.g., imipenem or amoxicillin-clavulanate) [78]. Despite high doses of $\beta$-lactams and continuous administration, desirable PK/PD targets (i.e., $>4$ MIC) may not be achieved in patients with augmented creatinine clearance [66]. Thus, given intra- and/or inter-individual PK variability and defined targets, experts recommend therapeutic drug monitoring in critically ill adult patients [79]. 


\section{Tissue Diffusion of Antibiotics}

Other features of NSTIs raise the interest of optimizing antibiotic tissue delivery, as despite urgent and extensive removal of necrotic tissues as a mainstem of management $[3,11,12]$, a median of 2 to 4 reinterventions are needed [4,7]. Local drug delivery may not only be impaired by global circulatory failure and the above discussed pharmacokinetic alterations induced by septic shock, but also by tissue necrosis and altered regional tissue perfusion from local micro-vessel dysfunction and thrombosis [60] (Figure 1). Available data approaching such conditions are derived from non-necrotizing SSTI, diabetic foot infection, acute limb ischemia, or acute pancreatitis-related necrosis infection. Only one recent study included 11 obese patients with severe SSTI, of whom 9 had NSTI, and evaluated the pharmacokinetics of linezolid. Although thought to have an excellent soft tissue distribution, the probability of target attainment for this drug was low using the standard dosing of $600 \mathrm{mg}$ every $12 \mathrm{~h}$, highlighting the importance of conducting specific studies in this specific population [80].

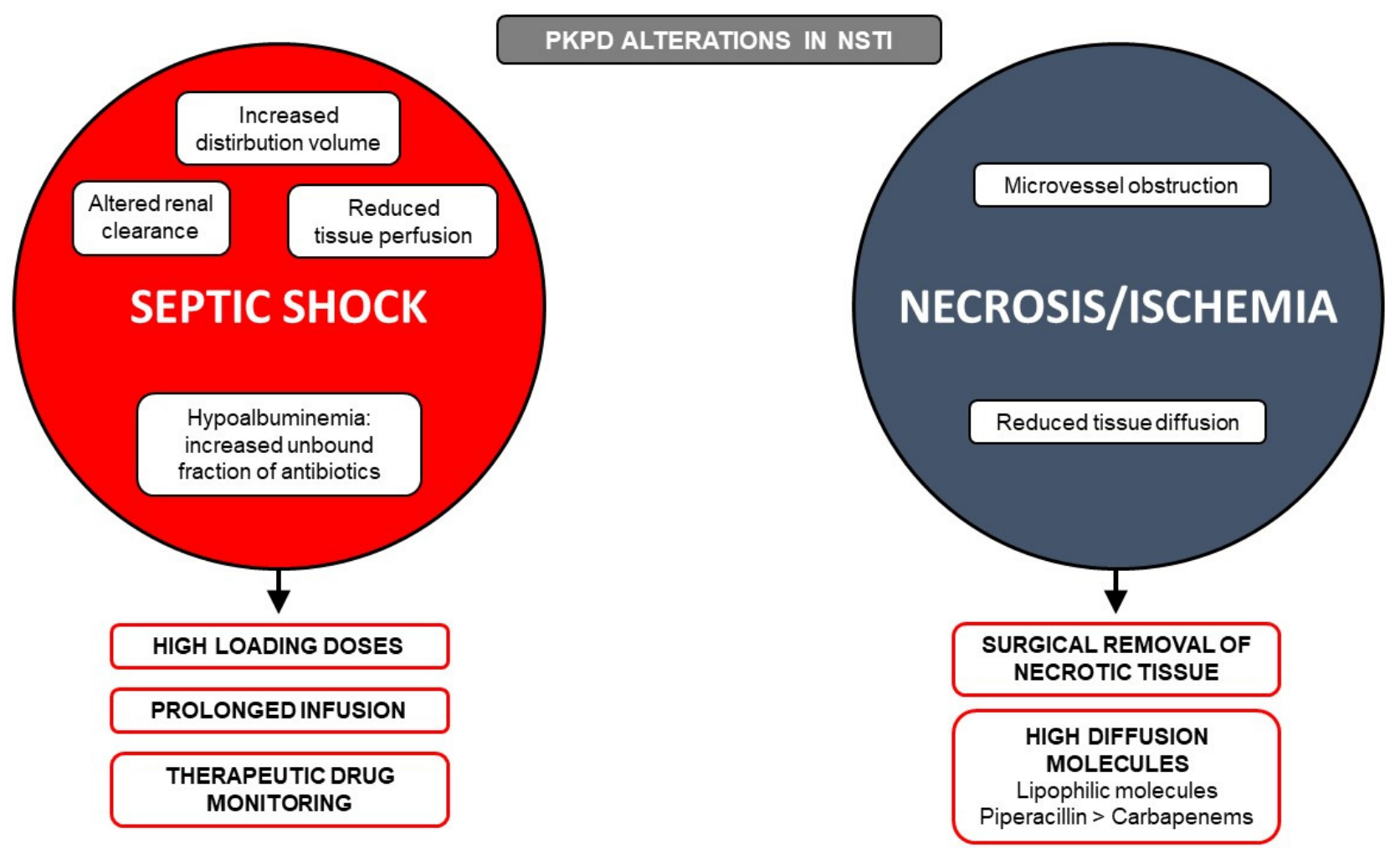

Figure 1. Pharmacokinetic (PK) and pharmacodynamic (PD) alterations in patients with necrotizing soft tissue infection (NSTI). Features of septic shock from any cause (increased distribution volume, altered renal clearance, hypoalbuminemia, and reduced tissue perfusion) abound for optimizing delivery of hydrophilic and time-dependent drugs such as betalactams by using high-loading doses and prolonged infusion with therapeutic drug monitoring. Specificities of NSTI with tissue necrosis and local ischemia resulting in hindered tissular diffusion are consistent with the need for urgent and aggressive surgical debridement of necrotic tissues. Molecules with higher tissue diffusion, such as lipophilic molecules (e.g., clindamycin, linezolid and daptomycin), might be of interest in this setting.

\subsection{Available Data from Uncomplicated SSTI}

Soft tissue distribution is reportedly high for lipophilic molecules, such as oxazolidinones, quinolones, macrolides, metronidazole, daptomycin and tigecycline [81-85]. Although, it was reported to be satisfactory for aminoglycosides [86]. Though it could be lower for beta-lactams [81,87], particularly in the case of high-protein binding [88], small scale pharmacokinetic studies on healthy subjects or monte-carlo simulations have found prolonged time periods above the minimum inhibitory concentrations $90\left(\mathrm{MIC}_{90}\right)$ of S. aureus and S. pyogenes in blisters for meropenem, imipenem and piperacillin-tazobactam [89,90], 
and high probabilities of target attainment for cefazolin in the interstitial fluid [91]. One recent study suggested higher probabilities of target attainment for ceftaroline than for vancomycin, linezolid or daptomycin, but it must be noted that this study was conducted by the firm licensing ceftaroline, and pooled data from literature not exclusively focusing on SSTI [92]. Takesue et al. found no correlation between PK/PD parameters and clinical success for daptomycin in uncomplicated S. aureus SSTIs [93]. Overall, data in non-necrotic SSTIs are reassuring regarding the use of beta-lactams for empiric therapy. Nevertheless, in the setting of severe SSTIs, such as NSTIs, optimizing PK/PD for such hydrophilic drugs by using high doses and continuous infusion could improve outcome and seems reasonable [81] (Table 2).

\section{STANDARD OF CARE} FOR EMPIRIC THERAPY

\section{GOOD PRACTICES}

ONGOING INVESTIGATION

\section{BROAD SPECTRUM BETALACTAM} (e.g. piperacillin-tazobactam)
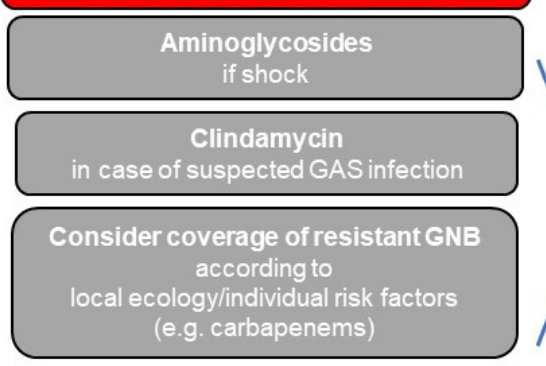

Consider anti-MRSA agents according to

local ecology/individual risk factors

(e.g. vancomycine/linezolid/daptomycin)

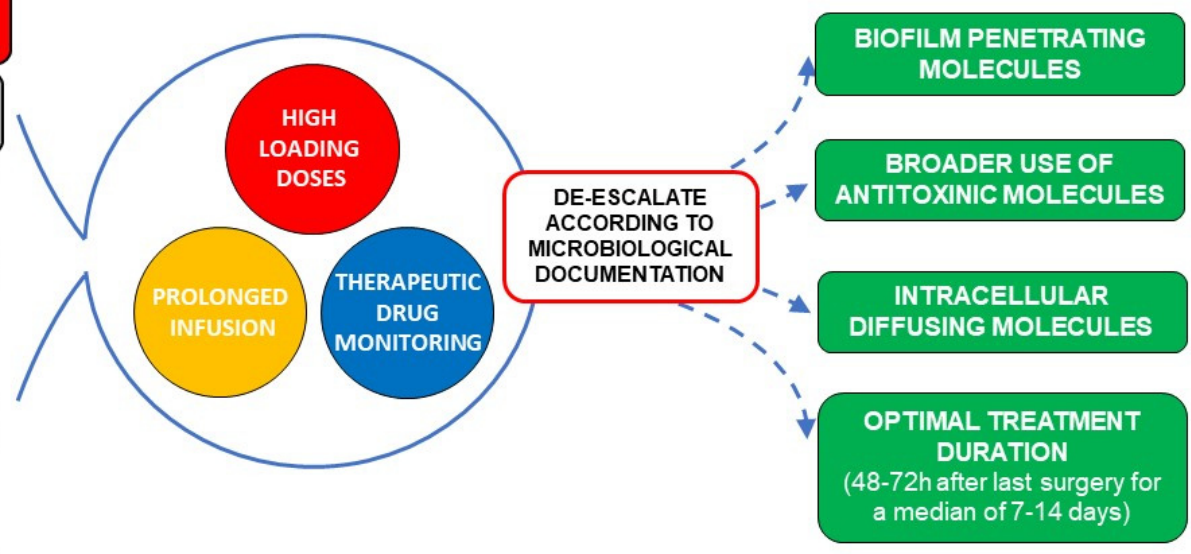

Figure 2. Suggested antibiotic treatment for necrotizing soft tissue infection (NSTI) and future perspectives. The mainstem of empiric treatment is a broad-spectrum beta-lactam (e.g., piperacillin-tazobactam) with additional aminoglycosides in case of septic shock. Clindamycin should be added in case of documented or suspected group A streptococcus (GAS) infection (limb infection, features of streptococcal toxic shock, absence of comorbidities, blunt trauma, absence of chronic skin lesions, homelessness, injectable drug use, non-steroidal anti-inflammatory drug use). Coverage of resistant gram-negative bacilli by carbapenems should be used according to local ecology and individual risk factors (hospital acquired infection, beta-lactam, or quinolone exposure in the previous 3 months, history of extended spectrum beta-lactamase (ESBL) carrying, germ colonization/infection or travel to high ESBL endemicity aeras in the previous 3 months). Similarly, use of anti-methicillin resistant Staphylococcus aureus (MRSA) drugs such as vancomycin, linezolid, or daptomycin should be considered in case of local endemicity, residence in a long-stay care facility, chronic dialysis, permanent transcutaneous medical devices or prior MRSA infection/colonization. Pharmacokinetics (PK) and Pharmacodynamics (PD) should be optimized by use of high-loading doses and prolonged infusions for molecules with time-dependent bactericidal activity such as beta-lactams, and therapeutic drug monitoring should be used when available. 


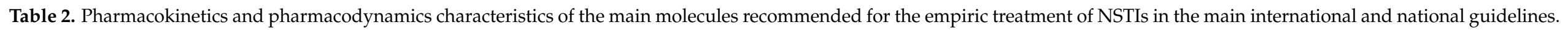

\begin{tabular}{|c|c|c|c|c|c|c|c|c|c|}
\hline \multirow[b]{2}{*}{ Molecule } & \multirow[b]{2}{*}{ Guidelines } & \multicolumn{3}{|c|}{ Pharmacokinetic Parameters } & \multicolumn{3}{|c|}{ Tissue Penetration (Tissue/Blood Ratio) } & \multirow[b]{2}{*}{$\begin{array}{c}\text { Antimicrobial } \\
\text { Spectrum/Anti- } \\
\text { Toxinic Activity and } \\
\text { other Specific Aspects }\end{array}$} & \multirow[b]{2}{*}{ Dosing Regimen $₫$} \\
\hline & & $\begin{array}{l}\text { Distribution } \\
\quad \text { (Vd) }\end{array}$ & $\begin{array}{l}\text { Protein } \\
\text { Binding }\end{array}$ & $\begin{array}{l}\text { PK/PD Targets in } \\
\text { Severe Infections }\end{array}$ & $\begin{array}{l}\text { Soft Tissue of } \\
\text { Healthy Subjects }\end{array}$ & $\begin{array}{c}\text { Impact of } \\
\text { Necrosis on } \\
\text { Tissue Diffusion }\end{array}$ & $\begin{array}{l}\text { Impact of Altered } \\
\text { Tissue Perfusion } \\
\text { on Tissue } \\
\text { Diffusion } \\
{[84,94-98]}\end{array}$ & & \\
\hline $\begin{array}{c}\text { Piperacillin + } \\
\text { tazobactam }\end{array}$ & $\begin{array}{c}\text { USA } 2014 \text { (IDSA) } \\
\text { World 2018 } \\
\text { (WSES/SIS-E) } \\
\text { Germany 2018 } \\
\text { South Korea } 2017\end{array}$ & $\begin{array}{l}\text { Hydrophilic } \\
(0.24 \mathrm{~L} / \mathrm{kg})\end{array}$ & $\begin{array}{c}\text { Low } \\
(16 \%)\end{array}$ & $\begin{array}{c}\mathrm{fT}>4-8 \times \mathrm{MIC}= \\
100 \%\end{array}$ & $\begin{array}{c}\text { Low } \\
(0.27)[81]^{*}\end{array}$ & $\begin{array}{c}\text { Medium to low } \\
\text { impact } \\
\text { (tissue } \\
\text { concentrations } \\
\text { appear sufficient } \\
\text { to achieve PK/PD } \\
\text { targets) }\end{array}$ & No data & $\begin{array}{c}\text { Methicillin- } \\
\text { susceptible } \text { S. aureus, } \\
\text { S. pyogenes, } \\
\text { Enterobacteriaceae, } \\
\text { nonfermenting bacilli, } \\
\text { anaerobic bacteria }\end{array}$ & $\begin{array}{c}4 \mathrm{~g} \text { q6h IV } \\
\text { Consider prolonged } \\
\text { (4 h) or continuous } \\
\text { infusion with } \\
\text { loading dose }\end{array}$ \\
\hline Cefotaxime & $\begin{array}{c}\text { USA } 2014 \\
\text { Norway } 2013 \\
\text { South Korea } 2017\end{array}$ & $\begin{array}{l}\text { Hydrophilic } \\
(0.28 \mathrm{~L} / \mathrm{kg})\end{array}$ & $\begin{array}{c}\text { Low } \\
(30-51 \%)\end{array}$ & $\begin{array}{c}\mathrm{fT}>4-8 \times \mathrm{MIC}= \\
100 \%\end{array}$ & $\begin{array}{c}\text { Medium } \\
(0.54)[99]^{\pi}\end{array}$ & $\begin{array}{l}\text { Medium to low } \\
\text { impact } \\
\text { (tissue } \\
\text { concentrations } \\
\text { appear sufficient } \\
\text { to achieve PK/PD } \\
\text { targets) }\end{array}$ & $\begin{array}{c}\text { No data } \\
\text { (but high decrease } \\
\text { of tissue } \\
\text { concentration with } \\
\text { others } \\
\text { cephalosporins: } \\
\text { cefepime [100] } \\
\text { and ceftazidime } \\
\text { [101]) } \\
\end{array}$ & $\begin{array}{c}\text { Methicillin- } \\
\text { susceptible S. aureus, } \\
\text { S. pyogenes, } \\
\text { Enterobacteriaceae }\end{array}$ & $2 \mathrm{~g} \mathrm{q} 6-8 \mathrm{~h} \mathrm{IV}$ \\
\hline Meropenem & $\begin{array}{c}\text { USA } 2014 \\
\text { World } 2018 \\
\text { Germany } 2018 \\
\text { South Korea } 2017\end{array}$ & $\begin{array}{l}\text { Hydrophilic } \\
(0.25 \mathrm{~L} / \mathrm{kg})\end{array}$ & $\begin{array}{l}\text { Very low } \\
(2 \%)\end{array}$ & $\begin{array}{c}\mathrm{fT}>4-8 \times \mathrm{MIC}= \\
100 \%\end{array}$ & $\begin{array}{c}\text { Low } \\
(0.35-0.48)[87]^{*}\end{array}$ & $\begin{array}{l}\text { Medium to high } \\
\text { decrease in drug } \\
\text { concentration } \\
\text { (tissue } \\
\text { concentrations } \\
\text { could not be } \\
\text { sufficient to } \\
\text { achieve PK/PD } \\
\text { targets) }\end{array}$ & Low impact & $\begin{array}{c}\text { Methicillin- } \\
\text { susceptible } S \text {. aureus, } \\
\text { S. pyogenes, } \\
\text { Enterobacteriaceae, } \\
\text { nonfermenting bacilli } \\
\text { anaerobic bacteria } \\
\text { activity on multi-drug } \\
\text { resistant } \\
\text { gram-negative bacilli }\end{array}$ & $\begin{array}{l}1-2 \mathrm{~g} \text { q } 8 \mathrm{~h} \mathrm{IV} \\
\text { Consider prolonged } \\
\text { infusion } 3 \mathrm{~h}\end{array}$ \\
\hline Gentamycin & Norway 2013 & $\begin{array}{l}\text { Hydrophilic } \\
(0.26 \mathrm{~L} / \mathrm{kg})\end{array}$ & $\begin{array}{l}\text { Very low } \\
(0-3 \%)\end{array}$ & $\mathrm{C}_{\max } / \mathrm{MIC}>8-10$ & $\begin{array}{l}\text { Medium } \\
(0.60)[81]^{*}\end{array}$ & $\begin{array}{l}\text { High decrease in } \\
\text { drug } \\
\text { concentration }\end{array}$ & No data & $\begin{array}{c}\text { S. aureus, S. pyogenes, } \\
\text { Enterobacteriaceae, } \\
\text { nonfermenting bacilli } \\
\text { Rapid bactericidal } \\
\text { action } \\
\text { Should be added in } \\
\text { cases of septic shock }\end{array}$ & $\begin{array}{l}5-8 \mathrm{mg} / \mathrm{kg} \text { over } \\
30 \mathrm{~min}, \mathrm{q} 24 \mathrm{~h}\end{array}$ \\
\hline
\end{tabular}


Table 2. Cont.

\begin{tabular}{|c|c|c|c|c|c|c|c|c|c|}
\hline \multirow[b]{2}{*}{ Molecule } & \multirow[b]{2}{*}{ Guidelines } & \multicolumn{3}{|c|}{ Pharmacokinetic Parameters } & \multicolumn{3}{|c|}{ Tissue Penetration (Tissue/Blood Ratio) } & \multirow[b]{2}{*}{$\begin{array}{c}\text { Antimicrobial } \\
\text { Spectrum/Anti- } \\
\text { Toxinic Activity and } \\
\text { other Specific Aspects }\end{array}$} & \multirow[b]{2}{*}{ Dosing Regimen $\$$} \\
\hline & & $\begin{array}{l}\text { Distribution } \\
\quad \text { (Vd) }\end{array}$ & $\begin{array}{l}\text { Protein } \\
\text { Binding }\end{array}$ & $\begin{array}{l}\text { PK/PD Targets in } \\
\text { Severe Infections }\end{array}$ & $\begin{array}{l}\text { Soft Tissue of } \\
\text { Healthy Subjects }\end{array}$ & $\begin{array}{c}\text { Impact of } \\
\text { Necrosis on } \\
\text { Tissue Diffusion }\end{array}$ & $\begin{array}{c}\text { Impact of Altered } \\
\text { Tissue Perfusion } \\
\text { on Tissue } \\
\text { Diffusion } \\
{[84,94-98]}\end{array}$ & & \\
\hline Amikacin & France 2018 & $\begin{array}{l}\text { Hydrophilic } \\
(0.26 \mathrm{~L} / \mathrm{kg})\end{array}$ & $\begin{array}{l}\text { Very low } \\
(<10 \%)\end{array}$ & $\mathrm{C}_{\max } / \mathrm{MIC}>8-10$ & $\begin{array}{c}\text { High } \\
(1.03)[86]^{\pi}\end{array}$ & $\begin{array}{c}\text { High decrease in } \\
\text { drug } \\
\text { concentration }\end{array}$ & No data & $\begin{array}{c}\text { S. aureus, S. pyogenes, } \\
\text { Enterobacteriaceae, } \\
\text { nonfermenting bacilli } \\
\text { Rapid bactericidal } \\
\text { action } \\
\text { Should be added in } \\
\text { cases of septic shock }\end{array}$ & $\begin{array}{l}25-30 \mathrm{~m} / \mathrm{kg} \text { over } \\
30 \mathrm{~min}, \mathrm{q} 24 \mathrm{~h}\end{array}$ \\
\hline Metronidazole & $\begin{array}{c}\text { USA } 2014 \\
\text { Norway } 2013 \\
\text { South Korea } 2017\end{array}$ & $\begin{array}{l}\text { Lipophilic } \\
(0.65 \mathrm{~L} / \mathrm{kg})\end{array}$ & $\begin{array}{l}\text { Very low } \\
(<10 \%)\end{array}$ & $\begin{array}{c}\mathrm{AUC}_{24} / \mathrm{MIC} \\
\mathrm{C}_{\max } / \mathrm{MIC} \\
\text { No target defined }\end{array}$ & $\begin{array}{c}\text { High } \\
(0.67)[85]\end{array}$ & No or low impact & No impact [102] & Anaerobic bacteria & $500 \mathrm{mg}$ q8h IV \\
\hline Vancomycin & $\begin{array}{c}\text { USA } 2014 \\
\text { South Korea } 2017\end{array}$ & $\begin{array}{l}\text { Hydrophilic } \\
(0.70 \mathrm{~L} / \mathrm{kg})\end{array}$ & $\begin{array}{l}\text { Medium } \\
(55 \%)\end{array}$ & $\begin{array}{c}\mathrm{AUC}_{24} / \mathrm{MIC}> \\
400-600\end{array}$ & $\begin{array}{c}\text { Low } \\
(0.30)[81]^{*}\end{array}$ & $\begin{array}{l}\text { Medium to high } \\
\text { decrease in drug } \\
\text { concentration }\end{array}$ & High impact [103] & $\begin{array}{l}\text { Methicillin-resistant } \\
\text { S. aureus }\end{array}$ & $\begin{array}{l}\text { Consider continuou } \\
\text { infusion of } \\
30 \mathrm{mg} / \mathrm{kg} / 24 \mathrm{~h} \text { witl } \\
\text { loading dose of } \\
30 \mathrm{mg} / \mathrm{kg} \text { and TDM }\end{array}$ \\
\hline Daptomycin & World 2018 & $\begin{array}{l}\text { Hydrophilic } \\
(0.10 \mathrm{~L} / \mathrm{kg})\end{array}$ & $\begin{array}{l}\text { High } \\
(92 \%)\end{array}$ & $\begin{array}{c}\mathrm{AUC}_{24} / \mathrm{MIC}>666 \\
{[104]}\end{array}$ & $\begin{array}{c}\text { High } \\
(0.74-0,93)[81]^{*}\end{array}$ & No data & No impact & $\begin{array}{l}\text { Methicillin-resistant } \\
\text { S. aureus }\end{array}$ & $8-12 \mathrm{mg} / \mathrm{kg}$ q24h \\
\hline Linezolid & $\begin{array}{c}\text { USA } 2014 \\
\text { World } 2018 \\
\text { South Korea } 2017\end{array}$ & $\begin{array}{l}\text { Lipophilic } \\
(0.65 \mathrm{~L} / \mathrm{kg})\end{array}$ & $\begin{array}{l}\text { Low } \\
(31 \%)\end{array}$ & $\begin{array}{c}\mathrm{AUC}_{24} / \mathrm{MIC}> \\
80-120 \\
\mathrm{fT}>1 \times \mathrm{MIC}= \\
85 \%[105]\end{array}$ & $\begin{array}{l}\text { High } \\
(0.75-1.32)[81]^{*}\end{array}$ & No data & No impact & $\begin{array}{l}\text { Methicillin-resistant } \\
\text { S. aureus } \\
\text { In vitro evidence of } \\
\text { anti-toxinic action }\end{array}$ & $\begin{array}{l}600 \mathrm{mg} \text { q12h IV } \\
\text { (higher doses migh } \\
\text { be needed in obese } \\
\text { patients [80]) }\end{array}$ \\
\hline Clindamycin & $\begin{array}{c}\text { World } 2018 \\
\text { Germany } 2018\end{array}$ & $\begin{array}{l}\text { Lipophilic } \\
(1.1 \mathrm{~L} / \mathrm{kg})\end{array}$ & $\begin{array}{l}\text { High } \\
(90 \%)\end{array}$ & $\begin{array}{c}\mathrm{AUC}_{24} / \mathrm{MIC} \\
\text { No target defined }\end{array}$ & $\begin{array}{l}\text { High } \\
(1.06)[106]^{x}\end{array}$ & No data & No impact & $\begin{array}{l}\text { S. aureus, S. pyogenes } \\
\text { Anaerobic bacteria } \\
\text { (but with high } \\
\text { proportion of resistant } \\
\text { strains), } \\
\text { High evidence of } \\
\text { in vivo and in vitro } \\
\text { anti-toxinic action }\end{array}$ & $600-900 \mathrm{mg}$ q8h IV \\
\hline
\end{tabular}

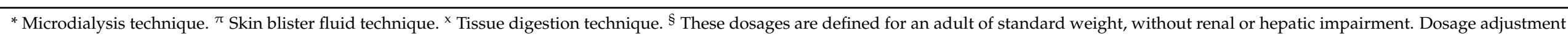

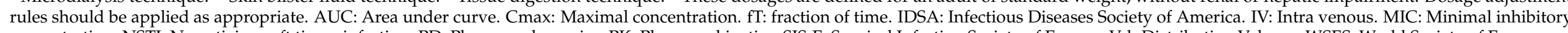

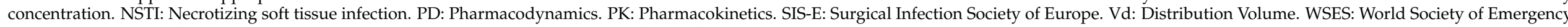

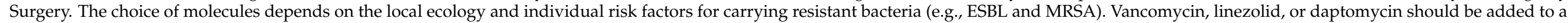

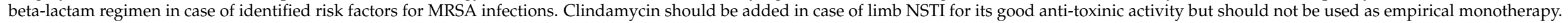
Aminoglycosides should be added in case of septic shock. Carbapenems should be added in case of risk factors for drug-resistant gram-negative bacilli (see Figure 2 legend). 


\subsection{Available Data on Antibiotic Diffusion in Necrotic Tissue}

These are derived from infection of necrosis in acute pancreatitis [107,108]. Although these are somewhat dated studies which did not use dosing regimens and administration modalities that are now the standard of care, they highlight the impact of molecule choice in tissue diffusion. Indeed, although the tissue/serum concentration ratio was high and tissue concentrations above the MICs of identified microorganisms were found for quinolones and metronidazole in the vast majority of patients, this was not always the case for betalactams, such as imipenem, and never the case for aminoglycosides. Tissue penetration was also suggested to be dependent on the degree of necrosis, inflammation, and regional perfusion [109]. In a recent literature review, piperacillin-tazobactam or cefepime diffusion into pancreatic tissue seemed superior to that of meropenem, abounding for the use of carbapenem only when resistant pathogens are suspected [110]. Although similar profiles are expected in skin and soft tissue necrosis, studies to evaluate the impact of molecule choice and administration modalities on tissue diffusion and outcome are needed in NSTI.

\subsection{Available Data on Antibiotic Diffusion in the Presence of Altered Perfusion}

Data is scarce regarding this issue, mainly derived from acute limb ischemia and diabetic foot infection. Interestingly, skin exudate antibiotic concentrations after intravenous administration were proposed as a means to evaluate local circulatory conditions, highlighting the link between tissue perfusion and drug delivery [111]. Experimental data from animal models have shown that even after ischemia has resolved, drug delivery can be hindered for as long as $72 \mathrm{~h}$ [112]. Lozano-Alonso et al. prospectively evaluated soft tissue and bone diffusion of antibiotics among 61 patients with acute limb ischemia requiring amputation [94]. Drug tissue concentration depended on tissue perfusion for vancomycin, levofloxacin, and ceftazidime, but not meropenem, clindamycin, or linezolid. Although diffusion of clindamycin is allegedly good in skin and soft tissue $[43,113]$ and was not affected by tissue perfusion, it did not reach adequate concentrations for the least sensitive strains, such as anaerobes of the Bacteroidetes genre, in this study. Others found no impact of ischemia on diffusion of metronidazole [102]. In diabetic foot infection, a condition known to be associated with altered local perfusion, lipophilic molecules such as daptomycin, linezolid, and trimethoprim-sulfamethoxazole have shown good tissue penetration [95-98], while it was altered for hydrophilic molecules such as vancomycin [103]. While ceftazidime penetration was not affected by diabetes, it highly depended on tissue perfusion in another work [101], and employing high doses is suggested for cefepime [100]. Maximal concentration in soft tissue was both reduced and delayed when compared to healthy-volunteers for tedizolid and ceftolozane-tazobactam [114,115]. Interestingly, tissue diffusion of linezolid in two patients was reported to improve after hyperbaric oxygen therapy, a therapeutic intervention sometimes employed in NSTIs [116].

Overall, data on antibiotic skin and soft tissue penetration in the setting of necrosis and altered perfusion abounds for improving PK/PD for hydrophilic molecules such as beta-lactams. Administration modalities should definitely be optimized with high-loading doses initially, continuous perfusion and therapeutic drug monitoring when available, as this has shown improved tissular penetration in other settings [77,117,118], but also in skin and soft-tissue infections, for example for piperacillin-tazobactam [88]. Whether the use of lipophilic drugs, less sensitive to such alterations, with higher reported tissue diffusion than beta-lactams such as clindamycin, quinolone, metronidazole, linezolid, daptomycin or tetracyclines has a beneficial impact on outcomes remains however unsettled. B-lactams, combined with clindamycin when there is a high probability of GAS infection, remain the mainstem of antibiotic treatment in NSTIs until such data are available.

There are only anecdotical reports on the use of topical antibiotics in NSTIs [119], as was suggested in necrotic pancreatitis [120]. Although their added benefit to parenteral treatment and surgery was not investigated, this approach does not seem suited as an exclusive first-line therapy. 


\section{Suggested Empiric Treatment for Suspected NSTI Based on Basic Microbiology}

The treatment of NSTIs relies on antibiotics and early surgical debridement, which is one of the most important modifiable prognostic factors [8]. With more than $50 \%$ of patients presenting with septic shock, urgent and bactericidal intravenous antibiotics are recommended [11,12]. NSTIs are often polymicrobial, and although some admission characteristics have been correlated with monomicrobial forms [18,121,122], even the site of infection is insufficient to guide empiric antibiotic treatment $[4,19,123,124]$. This should cover both gram positive, gram-negative, and anaerobic bacteria, usually with a broad-spectrum $\beta$-lactam (e.g., piperacillin-tazobactam). As discussed above, high-loading doses, continuous infusion, and therapeutic drug monitoring could improve the outcome. According to local ecology and individual risk factors, coverage of MRSA by glycopeptides or daptomycin, or of resistant gram-negatives by carbapenems should be considered on a case-by-case basis. Aminoglycosides should be reserved to broadening spectrum in case of septic shock. Finally, clindamycin adjunction seems adequate in the case of proven or suspected GAS infection (limb infection, features of streptococcal toxic shock, absence of comorbidities, blunt trauma, absence of chronic skin lesions, homelessness, injectable drug use, and non-steroidal anti-inflammatory drug use). In the absence of data, de-escalation of spectrum according to documentation seems reasonable, and suggested treatment duration is of $48-72 \mathrm{~h}$ after last surgery in case of clinical improvement [11,12]. A suggestion for management of antibiotic treatment in NSTI as well as future perspectives is presented in Figure 2.

\section{Conclusions}

Together with urgent surgical removal of necrotic tissues, antibiotics are the cornerstone of NSTI management, its mainstem being urgent bactericidal intravenous administration of a broad-spectrum beta-lactam such as piperacillin-tazobactam. Though no literature specifically focusing on NSTI exists, clinicians face the association of the profound $\mathrm{PK} / \mathrm{PD}$ alterations associated with sepsis (i.e., distribution volume increase, tissue necrosis, locally altered perfusion) hindering drug diffusion. Administration modalities should definitely be optimized with high initial loading doses, continuous antibiotic perfusions and therapeutic drug monitoring when available. Future research focusing on antibiotic strategies in NSTI patients should assess the use of drugs with higher reported tissue diffusion, broader use of anti-toxinic, biofilm, or intracellular penetrating molecules as well as the effect of different/personalized treatment durations.

Author Contributions: Conceptualization, T.U., N.d.P., Validation, T.U., K.R., C.O., P.-L.W., O.C., R.L., N.d.P., Writing—original draft preparation, T.U., K.R., C.O., P.-L.W., O.C., R.L., N.d.P.; Writingreview and editing, T.U., N.d.P.; Supervision, N.d.P.; All authors have read and agreed to the published version of the manuscript.

Funding: This research received no external funding.

Institutional Review Board Statement: Not applicable.

Informed Consent Statement: Not applicable.

Data Availability Statement: Not applicable.

Acknowledgments: The Henri Mondor Hospital Necrotizing Fasciitis Study Group: Romain Bosc, Olivier Chosidow, Nicolas de Prost, Camille Hua, Raphaël Lepeule, Lionel Nakad, Quentin De Roux, Tomas Urbina, and Paul-Louis Woerther.

Conflicts of Interest: Paul-Louis Woerther declares having received consulting fees from MSD. Other authors have no conflict of interest to disclose. 


\section{References}

1. Stevens, D.L.; Bryant, A.E. Necrotizing Soft-Tissue Infections. N. Engl. J. Med. 2017, 377, 2253-2265. [CrossRef]

2. Peetermans, M.; de Prost, N.; Eckmann, C.; Norrby-Teglund, A.; Skrede, S.; De Waele, J.J. Necrotizing Skin and Soft-Tissue Infections in the Intensive Care Unit. Clin. Microbiol. Infect. 2019, 26, 8-17. [CrossRef]

3. Urbina, T.; Madsen, M.B.; de Prost, N. Understanding Necrotizing Soft Tissue Infections in the Intensive Care Unit. Intensive Care Med. 2020, 46, 1739-1742. [CrossRef] [PubMed]

4. Madsen, M.B.; Skrede, S.; Perner, A.; Arnell, P.; Nekludov, M.; Bruun, T.; Karlsson, Y.; Hansen, M.B.; Polzik, P.; Hedetoft, M.; et al. Patient's Characteristics and Outcomes in Necrotising Soft-Tissue Infections: Results from a Scandinavian, Multicentre, Prospective Cohort Study. Intensive Care Med. 2019, 45, 1241-1251. [CrossRef] [PubMed]

5. Urbina, T.; Hua, C.; Sbidian, E.; Bosc, R.; Tomberli, F.; Lepeule, R.; Decousser, J.-W.; Mekontso Dessap, A.; Chosidow, O.; de Prost, N.; et al. Impact of a Multidisciplinary Care Bundle for Necrotizing Skin and Soft Tissue Infections: A Retrospective Cohort Study. Ann. Intensive Care 2019, 9, 123. [CrossRef] [PubMed]

6. Urbina, T.; Canoui-Poitrine, F.; Hua, C.; Layese, R.; Alves, A.; Ouedraogo, R.; Bosc, R.; Sbidian, E.; Chosidow, O.; Dessap, A.M.; et al. Long-Term Quality of Life in Necrotizing Soft-Tissue Infection Survivors: A Monocentric Prospective Cohort Study. Ann. Intensive Care 2021, 11, 102. [CrossRef]

7. Hua, C.; Sbidian, E.; Hemery, F.; Decousser, J.W.; Bosc, R.; Amathieu, R.; Rahmouni, A.; Wolkenstein, P.; Valeyrie-Allanore, L.; Brun-Buisson, C.; et al. Prognostic Factors in Necrotizing Soft-Tissue Infections (NSTI): A Cohort Study. J. Am. Acad. Dermatol. 2015, 73, 1006-1012.e8. [CrossRef]

8. Nawijn, F.; Smeeing, D.P.J.; Houwert, R.M.; Leenen, L.P.H.; Hietbrink, F. Time Is of the Essence When Treating Necrotizing Soft Tissue Infections: A Systematic Review and Meta-Analysis. World J. Emerg. Surg. 2020, 15, 4. [CrossRef]

9. Audureau, E.; Hua, C.; de Prost, N.; Hemery, F.; Decousser, J.W.; Bosc, R.; Lepeule, R.; Chosidow, O.; Sbidian, E. Henri Mondor Hospital Necrotizing Fasciitis group Mortality of Necrotizing Fasciitis: Relative Influence of Individual and Hospital-Level Factors, a Nationwide Multilevel Study, France, 2007-2012. Br. J. Dermatol. 2017, 177, 1575-1582. [CrossRef]

10. Hua, C.; Bosc, R.; Sbidian, E.; De Prost, N.; Hughes, C.; Jabre, P.; Chosidow, O.; Le Cleach, L. Interventions for Necrotizing Soft Tissue Infections in Adults. Cochrane Database Syst. Rev. 2018, 5, CD011680. [CrossRef]

11. Stevens, D.L.; Bisno, A.L.; Chambers, H.F.; Dellinger, E.P.; Goldstein, E.J.C.; Gorbach, S.L.; Hirschmann, J.V.; Kaplan, S.L.; Montoya, J.G.; Wade, J.C.; et al. Practice Guidelines for the Diagnosis and Management of Skin and Soft Tissue Infections: 2014 Update by the Infectious Diseases Society of America. Clin. Infect. Dis. 2014, 59, e10-e52. [CrossRef]

12. Sartelli, M.; Guirao, X.; Hardcastle, T.C.; Kluger, Y.; Boermeester, M.A.; Raşa, K.; Ansaloni, L.; Coccolini, F.; Montravers, P.; Abu-Zidan, F.M.; et al. 2018 WSES/SIS-E Consensus Conference: Recommendations for the Management of Skin and Soft-Tissue Infections. World J. Emerg. Surg. 2018, 13, 58. [CrossRef]

13. Kwak, Y.G.; Choi, S.-H.; Kim, T.; Park, S.Y.; Seo, S.-H.; Kim, M.B.; Choi, S.-H. Clinical Guidelines for the Antibiotic Treatment for Community-Acquired Skin and Soft Tissue Infection. Infect. Chemother. 2017, 49, 301. [CrossRef]

14. Sunderkötter, C.; Becker, K.; Eckmann, C.; Graninger, W.; Kujath, P.; Schöfer, H. S2k Guidelines for Skin and Soft Tissue Infections Excerpts from the S2k Guidelines for "Calculated Initial Parenteral Treatment of Bacterial Infections in Adults-Update 2018". J. Dtsch. Dermatol. Ges. 2019, 17, 345-369. [CrossRef]

15. Kao, L.S.; Lew, D.F.; Arab, S.N.; Todd, S.R.; Awad, S.S.; Carrick, M.M.; Corneille, M.G.; Lally, K.P. Local Variations in the Epidemiology, Microbiology, and Outcome of Necrotizing Soft-Tissue Infections: A Multicenter Study. Am. J. Surg. 2011, 202, 139-145. [CrossRef] [PubMed]

16. Chia, L.; Crum-Cianflone, N.F. Emergence of Multi-Drug Resistant Organisms (MDROs) Causing Fournier's Gangrene. J. Infect. 2018, 76, 38-43. [CrossRef]

17. Gunaratne, D.A.; Tseros, E.A.; Hasan, Z.; Kudpaje, A.S.; Suruliraj, A.; Smith, M.C.; Riffat, F.; Palme, C.E. Cervical Necrotizing Fasciitis: Systematic Review and Analysis of 1235 Reported Cases from the Literature. Head Neck 2018, 40, 2094-2102. [CrossRef]

18. Huang, T.-Y.; Peng, K.-T.; Hsiao, C.-T.; Fann, W.-C.; Tsai, Y.-H.; Li, Y.-Y.; Hung, C.-H.; Chuang, F.-Y.; Hsu, W.-H. Predictors for Gram-Negative Monomicrobial Necrotizing Fasciitis in Southern Taiwan. BMC Infect. Dis. 2020, 20, 60. [CrossRef]

19. INFECT study group; Thänert, R.; Itzek, A.; Hoßmann, J.; Hamisch, D.; Madsen, M.B.; Hyldegaard, O.; Skrede, S.; Bruun, T.; Norrby-Teglund, A.; et al. Molecular Profiling of Tissue Biopsies Reveals Unique Signatures Associated with Streptococcal Necrotizing Soft Tissue Infections. Nat. Commun. 2019, 10, 3846. [CrossRef]

20. Das, D.K.; Baker, M.G.; Venugopal, K. Risk Factors, Microbiological Findings and Outcomes of Necrotizing Fasciitis in New Zealand: A Retrospective Chart Review. BMC Infect. Dis. 2012, 12, 348. [CrossRef]

21. Bodansky, D.M.S.; Begaj, I.; Evison, F.; Webber, M.; Woodman, C.B.; Tucker, O.N. A 16-Year Longitudinal Cohort Study of Incidence and Bacteriology of Necrotising Fasciitis in England. World J. Surg. 2020, 44, 2580-2591. [CrossRef]

22. Miller, L.G.; Perdreau-Remington, F.; Rieg, G.; Mehdi, S.; Perlroth, J.; Bayer, A.S.; Tang, A.W.; Phung, T.O.; Spellberg, B. Necrotizing Fasciitis Caused by Community-Associated Methicillin-Resistant Staphylococcus Aureus in Los Angeles. N. Engl. J. Med. 2005, 352, 1445-1453. [CrossRef]

23. Lee, T.C.; Carrick, M.M.; Scott, B.G.; Hodges, J.C.; Pham, H.Q. Incidence and Clinical Characteristics of Methicillin-Resistant Staphylococcus Aureus Necrotizing Fasciitis in a Large Urban Hospital. Am. J. Surg. 2007, 194, 809-812. [CrossRef] [PubMed] 
24. Thy, M.; Tanaka, S.; Tran-Dinh, A.; Ribeiro, L.; Lortat-Jacob, B.; Donadio, J.; Zappella, N.; Ben-Rehouma, M.; Tashk, P.; Snauwaert, A.; et al. Dynamic Changes in Microbial Composition During Necrotizing Soft-Tissue Infections in ICU Patients. Front. Med. 2021, 7, 609497. [CrossRef] [PubMed]

25. Bruun, T.; Rath, E.; Madsen, M.B.; Oppegaard, O.; Nekludov, M.; Arnell, P.; Karlsson, Y.; Babbar, A.; Bergey, F.; Itzek, A.; et al. Risk Factors and Predictors of Mortality in Streptococcal Necrotizing Soft-Tissue Infections: A Multicenter Prospective Study. Clin. Infect. Dis. 2020, 72, 293-300. [CrossRef]

26. Bernigaud, C.; Chosidow, O. Are Swabs an Appropriate Way to Sample for Skin Microbiome Research? Br. J. Dermatol. 2019, 181, 444-445. [CrossRef]

27. Groupe Francophone de Réanimation et Urgences Pédiatriques (GFRUP); Réseau Mères-Enfants de la Francophonie (RMEF); Dauger, S.; Blondé, R.; Brissaud, O.; Marcoux, M.-O.; Angoulvant, F.; Levy, M. Necrotizing Soft-Tissue Infections in Pediatric Intensive Care: A Prospective Multicenter Case-Series Study. Crit. Care 2021, 25, 139. [CrossRef]

28. Kha, P.; Colot, J.; Gervolino, S.; Guerrier, G. Necrotizing Soft-Tissue Infections in New Caledonia: Epidemiology, Clinical Presentation, Microbiology, and Prognostic Factors. Asian J. Surg. 2017, 40, 290-294. [CrossRef]

29. Cornaglia, G.; Courcol, R.; Herrmann, J.-L.; Kahlmeter, G.; Peigue-Lafeuille, H.; Jordi, V. European Manual of Clinical Microbiology; European Society for Clinical Microbiology and Infections Diseases: Basel, Switzerland, 2012; ISBN 978-2-87805-026-4.

30. Norrby-Teglund, A.; Svensson, M.; Skrede, S. (Eds.) Necrotizing Soft Tissue Infections: Clinical and Pathogenic Aspects; Advances in Experimental Medicine and Biology; Springer International Publishing: Cham, Switzerland, 2020; Volume 1294, ISBN 978-3-03057615-8.

31. Wilson, M.R.; Sample, H.A.; Zorn, K.C.; Arevalo, S.; Yu, G.; Neuhaus, J.; Federman, S.; Stryke, D.; Briggs, B.; Langelier, C.; et al. Clinical Metagenomic Sequencing for Diagnosis of Meningitis and Encephalitis. N. Engl. J. Med. 2019, 380, 2327-2340. [CrossRef]

32. Thoendel, M.J.; Jeraldo, P.R.; Greenwood-Quaintance, K.E.; Yao, J.Z.; Chia, N.; Hanssen, A.D.; Abdel, M.P.; Patel, R. Identification of Prosthetic Joint Infection Pathogens Using a Shotgun Metagenomics Approach. Clin. Infect. Dis. 2018, 67, 1333-1338. [CrossRef] [PubMed]

33. Langelier, C.; Kalantar, K.L.; Moazed, F.; Wilson, M.R.; Crawford, E.D.; Deiss, T.; Belzer, A.; Bolourchi, S.; Caldera, S.; Fung, M.; et al. Integrating Host Response and Unbiased Microbe Detection for Lower Respiratory Tract Infection Diagnosis in Critically Ill Adults. Proc. Natl. Acad. Sci. USA 2018, 115, E12353-E12362. [CrossRef]

34. Rodriguez, C.; Jary, A.; Hua, C.; Woerther, P.-L.; Bosc, R.; Desroches, M.; Sitterlé, E.; Gricourt, G.; De Prost, N.; Pawlotsky, J.-M.; et al. Pathogen Identification by Shotgun Metagenomics of Patients with Necrotizing Soft-Tissue Infections. Br. J. Dermatol. 2019, 62. [CrossRef] [PubMed]

35. Charalampous, T.; Kay, G.L.; Richardson, H.; Aydin, A.; Baldan, R.; Jeanes, C.; Rae, D.; Grundy, S.; Turner, D.J.; Wain, J.; et al. Nanopore Metagenomics Enables Rapid Clinical Diagnosis of Bacterial Lower Respiratory Infection. Nat. Biotechnol. 2019, 37, 783-792. [CrossRef]

36. Brindle, R.; Williams, O.M.; Barton, E.; Featherstone, P. Assessment of Antibiotic Treatment of Cellulitis and Erysipelas: A Systematic Review and Meta-Analysis. JAMA Dermatol. 2019, 155, 1033. [CrossRef]

37. The STIC Study Group; Vick-Fragoso, R.; Hernández-Oliva, G.; Cruz-Alcázar, J.; Amábile-Cuevas, C.F.; Arvis, P.; Reimnitz, P.; Bogner, J.R. Efficacy and Safety of Sequential Intravenous/Oral Moxifloxacin vs Intravenous/Oral Amoxicillin/Clavulanate for Complicated Skin and Skin Structure Infections. Infection 2009, 37, 407-417. [CrossRef]

38. Eckmann, C.; Heizmann, W.; Bodmann, K.-F.; von Eiff, C.; Petrik, C.; Loeschmann, P.-A. Tigecycline in the Treatment of Patients with Necrotizing Skin and Soft Tissue Infections Due to Multiresistant Bacteria. Surg. Infect. 2015, 16, 618-625. [CrossRef]

39. Stevens, D.L.; Gibbons, A.E.; Bergstrom, R.; Winn, V. The Eagle Effect Revisited: Efficacy of Clindamycin, Erythromycin, and Penicillin in the Treatment of Streptococcal Myositis. J. Infect. Dis. 1988, 158, 23-28. [CrossRef]

40. Mascini, E.M.; Jansze, M.; Schouls, L.M.; Verhoef, J.; Van Dijk, H. Penicillin and Clindamycin Differentially Inhibit the Production of Pyrogenic Exotoxins A and B by Group A Streptococci. Int. J. Antimicrob. Agents 2001, 18, 395-398. [CrossRef]

41. Sriskandan, S.; McKee, A.; Hall, L.; Cohen, J. Comparative Effects of Clindamycin and Ampicillin on Superantigenic Activity of Streptococcus Pyogenes. J. Antimicrob. Chemother. 1997, 40, 275-277. [CrossRef] [PubMed]

42. Sawai, J.; Hasegawa, T.; Kamimura, T.; Okamoto, A.; Ohmori, D.; Nosaka, N.; Yamada, K.; Torii, K.; Ohta, M. Growth PhaseDependent Effect of Clindamycin on Production of Exoproteins by Streptococcus Pyogenes. Antimicrob. Agents Chemother. 2007, 51,461-467. [CrossRef]

43. Andreoni, F.; Zürcher, C.; Tarnutzer, A.; Schilcher, K.; Neff, A.; Keller, N.; Marques Maggio, E.; Poyart, C.; Schuepbach, R.A.; Zinkernagel, A.S. Clindamycin Affects Group A Streptococcus Virulence Factors and Improves Clinical Outcome. J. Infect. Dis. 2017, 215, 269-277. [CrossRef] [PubMed]

44. Eagle, H. Experimental Approach to the Problem of Treatment Failure with Penicillin. I. Group A Streptococcal Infection in Mice. Am. J. Med. 1952, 13, 389-399. [CrossRef]

45. Villalón, P.; Sáez-Nieto, J.A.; Rubio-López, V.; Medina-Pascual, M.J.; Garrido, N.; Carrasco, G.; Pino-Rosa, S.; Valdezate, S. Invasive Streptococcus Pyogenes Disease in Spain: A Microbiological and Epidemiological Study Covering the Period 2007-2019. Eur. J. Clin. Microbiol. Infect. Dis. 2021. [CrossRef]

46. Fay, K.; Onukwube, J.; Chochua, S.; Schaffner, W.; Cieslak, P.; Lynfield, R.; Muse, A.; Smelser, C.; Harrison, L.H.; Farley, M.; et al. Patterns of Antibiotic Nonsusceptibility among Invasive Group A Streptococcus Infections-United States, 2006-2017. Clin. Infect. Dis. 2021, ciab575. [CrossRef] [PubMed] 
47. Carapetis, J.R.; Jacoby, P.; Carville, K.; Ang, S.-J.J.; Curtis, N.; Andrews, R. Effectiveness of Clindamycin and Intravenous Immunoglobulin, and Risk of Disease in Contacts, in Invasive Group a Streptococcal Infections. Clin. Infect. Dis. 2014, $59,358-365$. [CrossRef]

48. Babiker, A.; Li, X.; Lai, Y.L.; Strich, J.R.; Warner, S.; Sarzynski, S.; Dekker, J.P.; Danner, R.L.; Kadri, S.S. Effectiveness of Adjunctive Clindamycin in $\beta$-Lactam Antibiotic-Treated Patients with Invasive $\beta$-Haemolytic Streptococcal Infections in US Hospitals: A Retrospective Multicentre Cohort Study. Lancet Infect. Dis. 2021, 21, 697-710. [CrossRef]

49. Coyle, E.A.; Cha, R.; Rybak, M.J. Influences of Linezolid, Penicillin, and Clindamycin, Alone and in Combination, on Streptococcal Pyrogenic Exotoxin a Release. Antimicrob. Agents Chemother. 2003, 47, 1752-1755. [CrossRef]

50. Siemens, N.; Chakrakodi, B.; Shambat, S.M.; Morgan, M.; Bergsten, H.; Hyldegaard, O.; Skrede, S.; Arnell, P.; Madsen, M.B.; Johansson, L.; et al. Biofilm in Group A Streptococcal Necrotizing Soft Tissue Infections. JCI Insight 2016, 1, e87882. [CrossRef]

51. Hertzén, E.; Johansson, L.; Kansal, R.; Hecht, A.; Dahesh, S.; Janos, M.; Nizet, V.; Kotb, M.; Norrby-Teglund, A. Intracellular Streptococcus Pyogenes in Human Macrophages Display an Altered Gene Expression Profile. PLoS ONE 2012, 7, e35218. [CrossRef] [PubMed]

52. Faraklas, I.; Yang, D.; Eggerstedt, M.; Zhai, Y.; Liebel, P.; Graves, G.; Dissanaike, S.; Mosier, M.; Cochran, A. A Multi-Center Review of Care Patterns and Outcomes in Necrotizing Soft Tissue Infections. Surg. Infect. 2016, 17, 773-778. [CrossRef]

53. on behalf of the REACH study group; Garau, J.; Blasi, F.; Medina, J.; McBride, K.; Ostermann, H. Early Response to Antibiotic Treatment in European Patients Hospitalized with Complicated Skin and Soft Tissue Infections: Analysis of the REACH Study. BMC Infect. Dis. 2015, 15, 78. [CrossRef] [PubMed]

54. Craig, W.A. Pharmacokinetic/Pharmacodynamic Parameters: Rationale for Antibacterial Dosing of Mice and Men. Clin. Infect. Dis. 1998, 26, 1-10. [CrossRef] [PubMed]

55. Gonçalves-Pereira, J.; Póvoa, P. Antibiotics in Critically Ill Patients: A Systematic Review of the Pharmacokinetics of $\beta$-Lactams. Crit. Care 2011, 15, R206. [CrossRef] [PubMed]

56. Ulldemolins, M.; Roberts, J.A.; Wallis, S.C.; Rello, J.; Lipman, J. Flucloxacillin Dosing in Critically Ill Patients with Hypoalbuminaemia: Special Emphasis on Unbound Pharmacokinetics. J. Antimicrob. Chemother. 2010, 65, 1771-1778. [CrossRef]

57. Joynt, G.M.; Lipman, J.; Gomersall, C.D.; Young, R.J.; Wong, E.L.; Gin, T. The Pharmacokinetics of Once-Daily Dosing of Ceftriaxone in Critically Ill Patients. J. Antimicrob. Chemother. 2001, 47, 421-429. [CrossRef]

58. Taccone, F.S.; Laterre, P.-F.; Dugernier, T.; Spapen, H.; Delattre, I.; Wittebole, X.; De Backer, D.; Layeux, B.; Wallemacq, P.; Vincent, J.-L.; et al. Insufficient $\beta$-Lactam Concentrations in the Early Phase of Severe Sepsis and Septic Shock. Crit. Care 2010, 14, R126. [CrossRef] [PubMed]

59. Delattre, I.K.; Taccone, F.S.; Jacobs, F.; Hites, M.; Dugernier, T.; Spapen, H.; Laterre, P.-F.; Wallemacq, P.E.; Van Bambeke, F.; Tulkens, P.M. Optimizing $\beta$-Lactams Treatment in Critically-Ill Patients Using Pharmacokinetics/Pharmacodynamics Targets: Are First Conventional Doses Effective? Expert Rev. Anti-Infect. Ther. 2017, 15, 677-688. [CrossRef]

60. Joukhadar, C.; Frossard, M.; Mayer, B.X.; Brunner, M.; Klein, N.; Siostrzonek, P.; Eichler, H.G.; Müller, M. Impaired Target Site Penetration of Beta-Lactams May Account for Therapeutic Failure in Patients with Septic Shock. Crit. Care Med. 2001, 29 , 385-391. [CrossRef]

61. Rhodes, A.; Evans, L.E.; Alhazzani, W.; Levy, M.M.; Antonelli, M.; Ferrer, R.; Kumar, A.; Sevransky, J.E.; Sprung, C.L.; Nunnally, M.E.; et al. Surviving Sepsis Campaign: International Guidelines for Management of Sepsis and Septic Shock: 2016. Intensive Care Med. 2017, 43, 304-377. [CrossRef]

62. Kumar, A.; Roberts, D.; Wood, K.E.; Light, B.; Parrillo, J.E.; Sharma, S.; Suppes, R.; Feinstein, D.; Zanotti, S.; Taiberg, L.; et al. Duration of Hypotension before Initiation of Effective Antimicrobial Therapy Is the Critical Determinant of Survival in Human Septic Shock. Crit. Care Med. 2006, 34, 1589-1596. [CrossRef] [PubMed]

63. Roberts, J.A.; Paul, S.K.; Akova, M.; Bassetti, M.; De Waele, J.J.; Dimopoulos, G.; Kaukonen, K.-M.; Koulenti, D.; Martin, C.; Montravers, P.; et al. DALI: Defining Antibiotic Levels in Intensive Care Unit Patients: Are Current -Lactam Antibiotic Doses Sufficient for Critically Ill Patients? Clin. Infect. Dis. 2014, 58, 1072-1083. [CrossRef]

64. Abdul-Aziz, M.H.; Sulaiman, H.; Mat-Nor, M.-B.; Rai, V.; Wong, K.K.; Hasan, M.S.; Abd Rahman, A.N.; Jamal, J.A.; Wallis, S.C.; Lipman, J.; et al. Beta-Lactam Infusion in Severe Sepsis (BLISS): A Prospective, Two-Centre, Open-Labelled Randomised Controlled Trial of Continuous versus Intermittent Beta-Lactam Infusion in Critically Ill Patients with Severe Sepsis. Intensive Care Med. 2016, 42, 1535-1545. [CrossRef]

65. Mohr, J.F.; Wanger, A.; Rex, J.H. Pharmacokinetic/Pharmacodynamic Modeling Can Help Guide Targeted Antimicrobial Therapy for Nosocomial Gram-Negative Infections in Critically Ill Patients. Diagn. Microbiol. Infect. Dis. 2004, 48, 125-130. [CrossRef] [PubMed]

66. Carrié, C.; Petit, L.; d’Houdain, N.; Sauvage, N.; Cottenceau, V.; Lafitte, M.; Foumenteze, C.; Hisz, Q.; Menu, D.; Legeron, R.; et al. Association between Augmented Renal Clearance, Antibiotic Exposure and Clinical Outcome in Critically Ill Septic Patients Receiving High Doses of $\beta$-Lactams Administered by Continuous Infusion: A Prospective Observational Study. Int. J. Antimicrob. Agents 2018, 51, 443-449. [CrossRef] [PubMed]

67. Li, C.; Du, X.; Kuti, J.L.; Nicolau, D.P. Clinical Pharmacodynamics of Meropenem in Patients with Lower Respiratory Tract Infections. Antimicrob. Agents Chemother. 2007, 51, 1725-1730. [CrossRef] 
68. McKinnon, P.S.; Paladino, J.A.; Schentag, J.J. Evaluation of Area under the Inhibitory Curve (AUIC) and Time above the Minimum Inhibitory Concentration ( $\mathrm{T}>\mathrm{MIC})$ as Predictors of Outcome for Cefepime and Ceftazidime in Serious Bacterial Infections. Int. J. Antimicrob. Agents 2008, 31, 345-351. [CrossRef] [PubMed]

69. Drusano, G.L. Antimicrobial Pharmacodynamics: Critical Interactions of "Bug and Drug”. Nat. Rev. Microbiol. 2004, 2, 289-300. [CrossRef] [PubMed]

70. Crandon, J.L.; Ariano, R.E.; Zelenitsky, S.A.; Nicasio, A.M.; Kuti, J.L.; Nicolau, D.P. Optimization of Meropenem Dosage in the Critically Ill Population Based on Renal Function. Intensive Care Med. 2011, 37, 632-638. [CrossRef] [PubMed]

71. Lodise, T.P.; Lomaestro, B.; Rodvold, K.A.; Danziger, L.H.; Drusano, G.L. Pharmacodynamic Profiling of Piperacillin in the Presence of Tazobactam in Patients through the Use of Population Pharmacokinetic Models and Monte Carlo Simulation Antimicrob. Agents Chemother. 2004, 48, 4718-4724. [CrossRef]

72. Lomaestro, B.M.; Drusano, G.L. Pharmacodynamic Evaluation of Extending the Administration Time of Meropenem Using a Monte Carlo Simulation. Antimicrob. Agents Chemother. 2005, 49, 461-463. [CrossRef]

73. Nicolau, D.P.; McNabb, J.; Lacy, M.K.; Quintiliani, R.; Nightingale, C.H. Continuous versus Intermittent Administration of Ceftazidime in Intensive Care Unit Patients with Nosocomial Pneumonia. Int. J. Antimicrob. Agents 2001, 17, 497-504. [CrossRef]

74. Roberts, J.A.; Kirkpatrick, C.M.J.; Roberts, M.S.; Dalley, A.J.; Lipman, J. First-Dose and Steady-State Population Pharmacokinetics and Pharmacodynamics of Piperacillin by Continuous or Intermittent Dosing in Critically Ill Patients with Sepsis. Int. J. Antimicrob. Agents 2010, 35, 156-163. [CrossRef] [PubMed]

75. Roberts, J.A.; Abdul-Aziz, M.-H.; Davis, J.S.; Dulhunty, J.M.; Cotta, M.O.; Myburgh, J.; Bellomo, R.; Lipman, J. Continuous versus Intermittent $\beta$-Lactam Infusion in Severe Sepsis. A Meta-Analysis of Individual Patient Data from Randomized Trials. Am. J. Respir. Crit. Care Med. 2016, 194, 681-691. [CrossRef] [PubMed]

76. Vardakas, K.Z.; Voulgaris, G.L.; Maliaros, A.; Samonis, G.; Falagas, M.E. Prolonged versus Short-Term Intravenous Infusion of Antipseudomonal $\beta$-Lactams for Patients with Sepsis: A Systematic Review and Meta-Analysis of Randomised Trials. Lancet Infect. Dis. 2018, 18, 108-120. [CrossRef]

77. Rhodes, N.J.; Liu, J.; O’Donnell, J.N.; Dulhunty, J.M.; Abdul-Aziz, M.H.; Berko, P.Y.; Nadler, B.; Lipman, J.; Roberts, J.A. Prolonged Infusion Piperacillin-Tazobactam Decreases Mortality and Improves Outcomes in Severely Ill Patients: Results of a Systematic Review and Meta-Analysis*. Crit. Care Med. 2018, 46, 236-243. [CrossRef] [PubMed]

78. Longuet, P.; Lecapitaine, A.L.; Cassard, B.; Batista, R.; Gauzit, R.; Lesprit, P.; Haddad, R.; Vanjak, D.; Diamantis, S. Groupe des référents en infectiologie d'Île-de-France (GRIF) Preparing and Administering Injectable Antibiotics: How to Avoid Playing God. Med. Mal. Infect. 2016, 46, 242-268. [CrossRef]

79. Abdul-Aziz, M.H.; Alffenaar, J.-W.C.; Bassetti, M.; Bracht, H.; Dimopoulos, G.; Marriott, D.; Neely, M.N.; Paiva, J.-A.; Pea, F.; Sjovall, F.; et al. Antimicrobial Therapeutic Drug Monitoring in Critically Ill Adult Patients: A Position Paper. Intensive Care Med. 2020, 46, 1127-1153. [CrossRef]

80. Blackman, A.L.; Jarugula, P.; Nicolau, D.P.; Chui, S.H.; Joshi, M.; Heil, E.L.; Gopalakrishnan, M. Evaluation of Linezolid Pharmacokinetics in Critically Ill Obese Patients with Severe Skin and Soft Tissue Infections. Antimicrob. Agents Chemother. 2021, 65. [CrossRef]

81. Pea, F. Practical Concept of Pharmacokinetics/Pharmacodynamics in the Management of Skin and Soft Tissue Infections. Curr. Opin. Infect. Dis. 2016, 29, 153-159. [CrossRef]

82. Barbour, A.; Scaglione, F.; Derendorf, H. Class-Dependent Relevance of Tissue Distribution in the Interpretation of Anti-Infective Pharmacokinetic/Pharmacodynamic Indices. Int. J. Antimicrob. Agents 2010, 35, 431-438. [CrossRef]

83. Sahre, M.; Sabarinath, S.; Grant, M.; Seubert, C.; DeAnda, C.; Prokocimer, P.; Derendorf, H. Skin and Soft Tissue Concentrations of Tedizolid (Formerly Torezolid), a Novel Oxazolidinone, Following a Single Oral Dose in Healthy Volunteers. Int. J. Antimicrob. Agents 2012, 40, 51-54. [CrossRef]

84. Stein, G.E.; Smith, C.L.; Missavage, A.; Saunders, J.P.; Nicolau, D.P.; Battjes, S.M.; Kepros, J.P. Tigecycline Penetration into Skin and Soft Tissue. Surg. Infect. 2011, 12, 465-467. [CrossRef]

85. Bielecka-Grzela, S.; Klimowicz, A. Application of Cutaneous Microdialysis to Evaluate Metronidazole and Its Main Metabolite Concentrations in the Skin after a Single Oral Dose. J. Clin. Pharm. Ther. 2003, 28, 465-469. [CrossRef]

86. Lanao, J.M.; Navarro, A.S.; Dominguez-Gil, A.; Tabernero, J.M.; Rodriguez, I.C.; Lopez, A.G. Amikacin Concentrations in Serum and Blister Fluid in Healthy Volunteers and in Patients with Renal Impairment. J. Antimicrob. Chemother. 1983, 12, 481-488. [CrossRef]

87. Simon, P.; Petroff, D.; Busse, D.; Heyne, J.; Girrbach, F.; Dietrich, A.; Kratzer, A.; Zeitlinger, M.; Kloft, C.; Kees, F.; et al. Meropenem Plasma and Interstitial Soft Tissue Concentrations in Obese and Nonobese Patients-A Controlled Clinical Trial. Antibiotics 2020, 9, 931. [CrossRef]

88. Kiang, T.K.L.; Häfeli, U.O.; Ensom, M.H.H. A Comprehensive Review on the Pharmacokinetics of Antibiotics in Interstitial Fluid Spaces in Humans: Implications on Dosing and Clinical Pharmacokinetic Monitoring. Clin. Pharm. 2014, 53, 695-730. [CrossRef] [PubMed]

89. Maglio, D.; Teng, R.; Thyrum, P.T.; Nightingale, C.H.; Nicolau, D.P. Pharmacokinetic Profile of Meropenem, Administered at 500 Milligrams Every 8 Hours, in Plasma and Cantharidin-Induced Skin Blister Fluid. Antimicrob. Agents Chemother. 2003, 47, 1771-1773. [CrossRef] 
90. Ong, C.T.; Kuti, J.L.; Nicolau, D.P. Pharmacodynamic Modeling of Imipenem-Cilastatin, Meropenem, and Piperacillin-Tazobactam for Empiric Therapy of Skin and Soft Tissue Infections: A Report from the OPTAMA Program. Surg. Infect. 2005, 6, 419-426. [CrossRef] [PubMed]

91. So, W.; Kuti, J.L.; Nicolau, D.P. Population Pharmacokinetics of Cefazolin in Serum and Tissue for Patients with Complicated Skin and Soft Tissue Infections (CSSTI). Infect. Dis. Ther. 2014, 3, 269-279. [CrossRef] [PubMed]

92. Cristinacce, A.; Wright, J.G.; Macpherson, M.; Iaconis, J.; Das, S. Comparing Probability of Target Attainment against Staphylococcus Aureus for Ceftaroline Fosamil, Vancomycin, Daptomycin, Linezolid, and Ceftriaxone in Complicated Skin and Soft Tissue Infection Using Pharmacokinetic/Pharmacodynamic Models. Diagn. Microbiol. Infect. Dis. 2021, 99, 115292. [CrossRef] [PubMed]

93. Takesue, Y.; Mikamo, H.; Kusachi, S.; Watanabe, S.; Takahashi, K.; Yoshinari, T.; Ishii, M.; Aikawa, N. Correlation between Pharmacokinetic/Pharmacodynamic Indices and Clinical Outcomes in Japanese Patients with Skin and Soft Tissue Infections Treated with Daptomycin: Analysis of a Phase III Study. Diagn. Microbiol. Infect. Dis. 2015, 83, 77-81. [CrossRef]

94. Lozano-Alonso, S.; Linares-Palomino, J.P.; Vera-Arroyo, B.; Bravo-Molina, A.; Hernández-Quero, J.; Ros-Díe, E. Evaluación de la capacidad de difusión tisular de antibióticos en isquemia de miembros inferiores. Enferm. Infecc. Y Microbiol. Clínica 2016, 34, 477-483. [CrossRef]

95. Grillon, A.; Argemi, X.; Gaudias, J.; Ronde-Ousteau, C.; Boeri, C.; Jenny, J.-Y.; Hansmann, Y.; Lefebvre, N.; Jehl, F. Bone Penetration of Daptomycin in Diabetic Patients with Bacterial Foot Infections. Int. J. Infect. Dis. 2019, 85, 127-131. [CrossRef]

96. Stein, G.E.; Throckmorton, J.K.; Scharmen, A.E.; Weiss, W.J.; Prokai, L.; Smith, C.L.; Havlichek, D.H. Tissue Penetration and Antimicrobial Activity of Standard- and High-Dose Trimethoprim/Sulfamethoxazole and Linezolid in Patients with Diabetic Foot Infection. J. Antimicrob. Chemother. 2013, 68, 2852-2858. [CrossRef] [PubMed]

97. Wiskirchen, D.E.; Shepard, A.; Kuti, J.L.; Nicolau, D.P. Determination of Tissue Penetration and Pharmacokinetics of Linezolid in Patients with Diabetic Foot Infections Using in Vivo Microdialysis. Antimicrob. Agents Chemother. 2011, 55, 4170-4175. [CrossRef] [PubMed]

98. Traunmüller, F.; Schintler, M.V.; Metzler, J.; Spendel, S.; Mauric, O.; Popovic, M.; Konz, K.H.; Scharnagl, E.; Joukhadar, C. Soft Tissue and Bone Penetration Abilities of Daptomycin in Diabetic Patients with Bacterial Foot Infections. J. Antimicrob. Chemother. 2010, 65, 1252-1257. [CrossRef]

99. Bergan, T.; Kalager, T.; Hellum, K.B.; Solberg, C.O. Penetration of Cefotaxime and Desacetylcefotaxime into Skin Blister Fluid. J. Antimicrob. Chemother. 1982, 10, 193-196. [CrossRef]

100. So, W.; Kuti, J.L.; Shepard, A.; Nugent, J.; Nicolau, D.P. Tissue Penetration and Exposure of Cefepime in Patients with Diabetic Foot Infections. Int. J. Antimicrob. Agents 2016, 47, 247-248. [CrossRef]

101. Raymakers, J.T.; Houben, A.J.; van der Heyden, J.J.; Tordoir, J.H.; Kitslaar, P.J.; Schaper, N.C. The Effect of Diabetes and Severe Ischaemia on the Penetration of Ceftazidime into Tissues of the Limb. Diabet. Med. 2001, 18, 229-234. [CrossRef]

102. Kerin, M.J.; Greenstein, D.; Chisholm, E.M.; Sheehan, S.J.; Kester, R.C. Is Antibiotic Penetration Compromised in the Ischaemic Tissues of Patients Undergoing Amputation? Ann. R. Coll. Surg. Engl. 1992, 74, 274-276.

103. Skhirtladze, K.; Hutschala, D.; Fleck, T.; Thalhammer, F.; Ehrlich, M.; Vukovich, T.; Müller, M.; Tschernko, E.M. Impaired Target Site Penetration of Vancomycin in Diabetic Patients Following Cardiac Surgery. Antimicrob. Agents Chemother. 2006, 50, 1372-1375. [CrossRef]

104. Safdar, N.; Andes, D.; Craig, W.A. In Vivo Pharmacodynamic Activity of Daptomycin. Antimicrob. Agents Chemother. 2004, 48, 63-68. [CrossRef]

105. Andes, D.; van Ogtrop, M.L.; Peng, J.; Craig, W.A. In Vivo Pharmacodynamics of a New Oxazolidinone (Linezolid). Antimicrob. Agents Chemother. 2002, 46, 3484-3489. [CrossRef]

106. Berger, S.A.; Barza, M.; Haher, J.; McFarland, J.J.; Louie, S.; Kane, A. Penetration of Clindamycin into Decubitus Ulcers. Antimicrob. Agents Chemother. 1978, 14, 498-499. [CrossRef] [PubMed]

107. Bassi, C.; Pederzoli, P.; Vesentini, S.; Falconi, M.; Bonora, A.; Abbas, H.; Benini, A.; Bertazzoni, E.M. Behavior of Antibiotics during Human Necrotizing Pancreatitis. Antimicrob. Agents Chemother. 1994, 38, 830-836. [CrossRef] [PubMed]

108. Minelli, E.B.; Benini, A.; Muner, A.; Bassi, C.; Abbas, H.; Pederzoli, P. Pefloxacin Penetration into Human Necrotic Pancreatic Tissue. J. Antimicrob. Chemother. 1996, 38, 237-243. [CrossRef] [PubMed]

109. Foitzik, T.; Hotz, H.G.; Kinzig, M.; Sörgel, F.; Buhr, H.J. Influence of Changes in Pancreatic Tissue Morphology and Capillary Blood Flow on Antibiotic Tissue Concentrations in the Pancreas during the Progression of Acute Pancreatitis. Gut 1997, 40, 526-530. [CrossRef]

110. Maguire, C.; Agrawal, D.; Daley, M.J.; Douglass, E.; Rose, D.T. Rethinking Carbapenems: A Pharmacokinetic Approach for Antimicrobial Selection in Infected Necrotizing Pancreatitis. Ann. Pharmacother. 2021, 55, 902-913. [CrossRef]

111. Gowland Hopkins, N.F.; Jamieson, C.W. Antibiotic Concentration in the Exudate of Venous Ulcers: The Prediction of Ulcer Healing Rate. Br. J. Surg. 1983, 70, 532-534. [CrossRef]

112. Mangum, L.C.; Garcia, G.R.; Akers, K.S.; Wenke, J.C. Duration of Extremity Tourniquet Application Profoundly Impacts Soft-Tissue Antibiotic Exposure in a Rat Model of Ischemia-Reperfusion Injury. Injury 2019, 50, 2203-2214. [CrossRef]

113. Duckworth, C.; Fisher, J.F.; Carter, S.A.; Newman, C.L.; Cogburn, C.; Nesbit, R.R.; Wray, C.H. Tissue Penetration of Clindamycin in Diabetic Foot Infections. J. Antimicrob. Chemother. 1993, 31, 581-584. [CrossRef] 
114. Stainton, S.M.; Monogue, M.L.; Baummer-Carr, A.; Shepard, A.K.; Nugent, J.F.; Kuti, J.L.; Nicolau, D.P. Comparative Assessment of Tedizolid Pharmacokinetics and Tissue Penetration between Diabetic Patients with Wound Infections and Healthy Volunteers via In Vivo Microdialysis. Antimicrob. Agents Chemother. 2018, 62. [CrossRef] [PubMed]

115. Monogue, M.L.; Stainton, S.M.; Baummer-Carr, A.; Shepard, A.K.; Nugent, J.F.; Kuti, J.L.; Nicolau, D.P. Pharmacokinetics and Tissue Penetration of Ceftolozane-Tazobactam in Diabetic Patients with Lower Limb Infections and Healthy Adult Volunteers. Antimicrob. Agents Chemother. 2017, 61, e01449-17. [CrossRef]

116. Koomanachai, P.; Keel, R.A.; Johnson-Arbor, K.K.; Suecof, L.A.; Nicolau, D.P.; Kuti, J.L. Linezolid Penetration into Wound Tissue of Two Diabetic Patients before and after Hyperbaric Oxygen Therapy. Undersea Hyperb. Med. 2011, 38, 11-16.

117. Boselli, E.; Breilh, D.; Rimmelé, T.; Guillaume, C.; Xuereb, F.; Saux, M.-C.; Bouvet, L.; Chassard, D.; Allaouchiche, B. Alveolar Concentrations of Piperacillin/Tazobactam Administered in Continuous Infusion to Patients with Ventilator-Associated Pneumonia. Crit. Care Med. 2008, 36, 1500-1506. [CrossRef] [PubMed]

118. Skopnik, H.; Heimann, G. Pharmacokinetics of Antimicrobial Drugs in the Cerebrospinal Fluid. Pediatr. Pharmacol. 1983, 3 , 313-320.

119. Murali, S.; Pillai, A.V.; Ramachandran, R. Efficacy of Colistimethate Sodium as Local Application in Necrotising Fasciitis. BMJ Case Rep. 2019, 12, e232354. [CrossRef]

120. González-López, J.; Macías-García, F.; Lariño-Noia, J.; Domínguez-Muñoz, J.E. Theoretical Approach to Local Infusion of Antibiotics for Infected Pancreatic Necrosis. Pancreatology 2016, 16, 719-725. [CrossRef]

121. Urbina, T.; Hua, C.; Woerther, P.-L.; Mekontso Dessap, A.; Chosidow, O.; de Prost, N. Early Identification of Patients at High Risk of Group A Streptococcus-Associated Necrotizing Skin and Soft Tissue Infections: A Retrospective Cohort Study. Crit. Care 2019, 23, 417. [CrossRef]

122. Willis, R.N.; Guidry, C.A.; Horn, C.B.; Gilsdorf, D.; Davies, S.W.; Dietch, Z.C.; Sawyer, R.G. Predictors of Monomicrobial Necrotizing Soft Tissue Infections. Surg. Infect. 2015, 16, 533-537. [CrossRef]

123. Brook, I.; Frazier, E.H. Clinical and Microbiological Features of Necrotizing Fasciitis. J. Clin. Microbiol. 1995, 33, $2382-2387$. [CrossRef]

124. Wattel, F.; Mathieu, D.; Neut, C.; Dubreuil, L.; Cesari, J.-F.; Favory, R. Necrotizing soft tissue infections: Role of the localization for the antibiotic management. Bull. Acad. Natl. Med. 2004, 188, 473-486. [PubMed] 